\title{
Factors Affecting Same-Day Discharge Following Laparoscopic Cholecystectomy in Children
}

\section{Çocuklarda Laparoskopik Kolesistektominin Günübirlik Uygulanmasını Etkileyen Faktörler}

\author{
Zafer Dökümcü, Emre Divarcı, Sibel Tiryaki, Ahmet Çelik, Geylani Özok, Orkan Ergün \\ Ege University Faculty of Medicine, Department of Pediatric Surgery, Izmir, Turkey
}

\begin{abstract}
Aim: Laparoscopic cholecystectomy (LC) as day surgery is widely performed on adults; however, experience in pediatric LC in an out-patient setting is limited. We aimed to review our experience and investigate related factors. Materials and Methods: Medical records of patients who underwent elective LC from June 2005 to July 2016 were retrospectively reviewed. Patients were grouped according to the duration of hospital stay, and patient characteristics and outcome were compared. T-test and chi-square were used for statistical analysis.

Results: A hundred and sixty-seven patients with a mean age of 10.4 years were enrolled. There was no conversion to open surgery, with only one postoperative complication in a patient with consumption coagulopathy. Same-day discharge (SDD), overnight stay (ONS) and prolonged stay (PS) groups were constituted of 50, 92, 25 patients respectively. All groups had similar preoperative characteristics and median postoperative pain scores. Previous history of cholecystitis and underlying hematological diseases were more common in the PS group ( $p<0.05$ ). Duration of anesthesia was shortest in $\mathrm{SDD}$, longest in $\mathrm{PS}$ groups $(\mathrm{p}<0.006)$. Perioperative minor complications were more common in the PS group than the SDD group ( $\mathrm{p}=0.03)$. Mean time for oral feeding was 3.2, 5.4 and 14.8 hours for SDD, ONS and PS groups respectively ( $p<0.009)$. There was no readmission.

Conclusion: LC may safely be performed as day surgery in children without comorbidities. Shorter duration of anesthesia and early oral feeding seem to play a key role in SDD in these cases.
\end{abstract}

Keywords: Laparoscopic cholecystectomy, day surgery, child
$0 ̈ Z$

Amaç: Erişkinlerde günübirlik laparoskopik kolesistektomi (LK) yaygın olarak kullanılmaktadır. Çocuklarda ise bu konuyla ilgili deneyim sinırıdır. Bu çalışmada çocuklarda günübirlik LK uygulamasını etkileyen faktörlerin ortaya konması amaçlanmıştır.

Gereç ve Yöntemler: Haziran 2005-Temmuz 2016 tarihleri arasında kliniğimizde semptomatik veya asemptomatik kolelitiyazis nedeniyle elektif LK uygulanmış hastaların kayıtları geriye dönük olarak incelendi. Hastalar yatış sürelerine göre gruplandırıldı. Gruplar; demografik veriler, eşlik eden hastalık, öykü, anestezi ve ameliyat özellikleri, postoperatif tedavi ve beslenme durumlarına göre karşılaştıııldı. Analiz için t-test ve ki-kare kullanıldı.

Bulgular: Ortalama yaşı 10,4 olan 167 olgu çalışmaya dahil edildi. Hiçbir olguda açığa dönüş gerekmezken tüketim koagülopatisi gelişen bir olgu dışında komplikasyon gelişmedi. Günübirlik (GB), tek gecelik yatış (TGY) ve uzamış yatış (UY) gruplarını sırasıyla 50, 92 ve 25 olgu oluşturdu. Gruplar preoperatif özellik ve postoperatif ağrı düzeyi açılarından benzerdi. Geçirilmiş kolesistit öyküsü UY grubunda daha sıktı $(p<0,05)$. Anestezi süresi GB grubunda en az, UY grubunda en fazlaydı ( $p<0,006)$. UY grubunda perioperatif minör komplikasyonlar $\mathrm{GB}$ grubuna göre daha sıktı $(\mathrm{p}=0,03)$. Oral beslenmeye geçiş süreleri GB, TGY ve UY gruplarında sırasılyla 3,2, 5,4 ve 14,8 saatti $(p<0,009)$. Hiçbir olguda yeniden yatış gerekmedi.

Sonuç: GB LK eşlik eden hastalığı olmayan çocuklarda güvenle uygulanabilir. Anestezi süresi ve oral beslenmenin geciktirimeden başlanması en önemli faktörlerdir.

Anahtar Kelimeler: Laparoskopik kolesistektomi, günübirlik, çocuk 


\section{Introduction}

The concept of day surgery has developed almost at the same time as the establishment of surgical facilities such as dispensaries or out-patient clinics since the early 1900's (1). Circumcisions, abscess drainages, excisions of glands along with amputations, hernias, and cleft palates were being carried out on an out-patient basis at that time. Decades later in the 1990's, with technical improvements and the development of minimal invasive surgery, laparoscopic cholecystectomy (LC) also became one of the day surgery procedures in adults. What is more, special units such as ambulatory surgery centers and post surgery recovery centers were established to minimize the cost and risk of patients (2). There are very few studies with a low number of patients on out-patient LC in the pediatric population. In this study we aimed to evaluate our experience in LC in terms of day surgery.

\section{Materials and Methods}

After Ege University Local Ethics Committee approved the study (approval number: 17-5.2/6), we reviewed the medical charts of patients with cholelithiasis who had undergone elective LC in our institution through June 2005 to July 2016. All participants' parents had signed consent form. Demographics, pre-operative imaging results, underlying hematological pathologies, and pre-surgical, surgical and post-surgical data were evaluated. Patients with additional procedures and urgent interventions were excluded. Groups were constituted according to the duration of in-hospital stay time (IHST); patients who were discharged on the same-day discharge (SDD) group, patients who stayed overnight stay (ONS) group and patients who had to stay more than 24 hours prolonged stay (PS) group. The groups were compared by means of data that could affect IHST.

\section{Statistical Analysis}

For statistical analysis, nominal values were evaluated with the chi-square test, and numeric values with twotailed Student's t-test. $P<0.05$ was considered statistically significant.

\section{Results}

A total of 167 children (78 girls, 89 boys) were enrolled in the study. Mean operation age was 10.4 (1-18) years. Twentyeight of the cases $(16.8 \%$ ) had underlying hemolytic diseases (hereditary spherocytosis in 11, thalassemia in 8 , sickle cell disease in 7, and glucose-6-phosphate dehydrogenase deficiency in 2). The majority of the patients ( $n=102,61.1 \%$ ) had history of non-specific abdominal pain at admission, and 18 patients $(10.8 \%)$ who had history of cholecystitis had been symptom-free for at least 3 months. Cholelithiasis was confirmed by preoperative ultrasonography in all patients. Seven children (4.2\%) had co-existing stones in distal of the gallbladder. These patients had undergone prior endoscopic sphincterotomies and cystic channels were cleared with saline flushing in all during surgery.

All cholecystectomies were performed by either board certified surgeons or surgical residents under the supervision of board certified surgeons. Majority of the procedures (126, 75.4\%) ended before 12:00 pm. Postoperative feeding regimes differed from early oral intake (minimum postoperative 3 hours) to oral feeding on the next day of surgery according to the surgeon's preference.

All patients received preoperative sedation with midazolam hydrochloride and were ventilated via an endotracheal tube with air, oxygen, and isoflurane. Intraoperative analgesia comprised intravenous fentanyl. In addition, all patients received intraoperative diclofenac or paracetamol where appropriate for age. All patients had infiltration of $0.25 \%$ levobupivacaine hydrochloride at port sites. Nasogastric drainage tube was used for all LC patients intraoperatively and prophylactic anti-emesis was provided by dexamethasone.

Minor perioperative complications including adhesions, gallbladder perforation, and bleeding were noted in 22 patients (13.2\%), and conversion was necessary for none. Mean operation time was 101.1 (45-240) minutes. None of the patients required additional analgesia other than the routinely administered perioperative and postoperative acetaminophen (10 mg/kg per oral q6hr) and metamizole sodium [25 mg/kg intravenous (i.v.)]. The postoperative feeding regime differed from unrestricted to a light diet depending on the surgeon's choice. The pain was assessed at least twice (at the time of postoperative ward reception and before discharge) by the nurses and was scored using the wong and baker faces pain rating scale (3). All patients were seen at the end of the afternoon by the surgical and nursing team, and decision regarding discharge was left to the patients' families when it was appropriate. Discharge criteria were; the ability to be fed normally, being pain-free, and willing to leave. None of the patients were discharged after 22:00 pm. Postoperative period was uneventful for all the patients but one, a girl with a giant arteriovenous malformation, who developed consumption coagulopathy and required further hematological evaluation and treatment.

SDD, ONS, and PS groups consisted of 50, 92 and 25 patients respectively, and the difference of mean IHST for each group was statistically significant $(p=0.000)$. The difference between mean age and gender distribution among groups was insignificant. History of cholecystitis and underlying hematological diseases were significantly higher in the PS group than the SDD and ONS groups $(p=0.03$ and 0.007). Mean operation times were 84.5, 103.9 and 117.7 minutes for SDD, ONS, and PS group respectively, and the difference between the SDD group with the ONS and PS group was significant $(p=0.005$ and 0.004$)$. Minor perioperative complications including difficult dissection due to adhesions, gallbladder perforation, and minor bleeding were significantly higher in the PS group than the SDD group $(p=0.03)$. 
Dökümcü et al.

Laparoscopic Cholecytectomy as Day Case Surgery in Children

Mean postoperative time for oral feeding (PTOF) was significantly different between the SDD (3.2 hours), ONS (5.4 hours) and PS (14.8 hours) groups ( $p=0.001,0.002$ and 0.008 ). The difference between mean pain scores before discharge was insignificant for all groups and none of the patients required readmission. The comparison of preoperative, perioperative, and postoperative data of the three groups is depicted in Table I.

\begin{tabular}{|c|c|c|c|c|}
\hline & $\begin{array}{l}\text { SDD group } \\
(n=50)\end{array}$ & $\begin{array}{l}\text { ONS group } \\
(n=92)\end{array}$ & $\begin{array}{l}\text { PS group } \\
(n=25)\end{array}$ & p \\
\hline Mean age (years) & $10.7(0.5-18)$ & $10.6(1-18)$ & $9.2(1.5-17)$ & $>0.05$ \\
\hline Gender (boys/girls) & $22 / 15$ & $43 / 39$ & $12 / 11$ & $>0.05$ \\
\hline History of cholecystitis & $3(8.1 \%)$ & $6(7.3 \%)$ & $6(26.1 \%)$ & 0.03 \\
\hline $\begin{array}{l}\text { Underlying } \\
\text { hematological disease }\end{array}$ & $8(21.6 \%)$ & $9(11 \%)$ & $9(39.1 \%)$ & 0.007 \\
\hline $\begin{array}{l}\text { Mean operation time } \\
\text { (minutes) }\end{array}$ & $84.5(45-174)$ & $103.9(46-188)$ & $117.7(60-240)$ & $\begin{array}{l}0.005 \\
0.004\end{array}$ \\
\hline $\begin{array}{l}\text { Perioperative } \\
\text { complication }\end{array}$ & $3(8.1 \%)$ & $9(11 \%)$ & $7(30.4 \%)$ & 0.03 \\
\hline PTOF (hours) & $3.2(1.5-6)$ & $5.4(1-18)$ & $14.8(1-72)$ & $\begin{array}{l}0.001 \\
0.002 \\
0.008\end{array}$ \\
\hline $\begin{array}{l}\text { Median postoperative } \\
\text { pain score }\end{array}$ & $2(0-4)$ & $3(0-4)$ & $3(0-5)$ & $>0.05$ \\
\hline IHST (hours) & $10.1(5-12)$ & $20.8(16-36)$ & $58.9(36-124)$ & 0.000 \\
\hline \multicolumn{5}{|c|}{$\begin{array}{l}\text { SDD: Same-day discharge, ONS: Overnight stay, PS: Prolonged stay, PTOF: Postoperative } \\
\text { time for oral feeding, IHST: In-hospital stay time }\end{array}$} \\
\hline
\end{tabular}

\section{Discussion}

Today LC as a well-established option is the gold standard treatment in symptomatic cholelithiasis. According to adult series, LC may be performed on ambulatory setting safely and there seems to be no significant difference in terms of pain scores, readmission rates, quality of life and patient anxiety between outpatient procedures and procedures with an ONS $(2,4-8)$. There are few studies related to LC as day surgery in children. In 2007 Méndez et al. (9) stated that LC may safely be performed on children as an out-patient procedure, but patients with co-morbidities benefit from an ONS. Despite a limited number of patients, their statement seems to be in parallel with our study. Agarwal and Bagdi (10) also showed the success of SDD in 11 patients. In 2013 Jawaheer et al. (11) proposed a clinical pathway for a day-case LC in 18 children. Dalton et al. (12) emphasized the importance of an SDD protocol to change conservative clinical habits to an outpatient approach. Readmission rate and related operations following LC as SDD were not different between in-hospital and out-patient LC cases in a recent study (13).

As also indicated by previous studies, out-patient surgery is widely performed for many different types of pathologies in pediatric surgery centers but there seems to be a legitimate skepticism for the day-case approach in gastrointestinal surgery although reports of laparoscopic fundoplication and laparoscopic appendectomy on children in an out-patient setting were recently published $(14,15)$. Doubtlessly, patient safety can not be jeopardized against all hospital costs, parental issues and surgeons' will, but we believe there is sufficient data in the literature showing that SDD for LC is safe and feasible for children as it is for adults with appropriate patient selection bias and management. Age, preoperative and operative morbidities such as previous history of cholecystitis and underlying hematological diseases, the length of anesthesia, may be considered as factors that may have an influence on the decision of the surgeon for early discharge, and these are yet to be discussed in this article.

Age: As seen in our study population, age does not seem to affect the decision for SDD. The youngest patient was a 6-month-old girl in the SDD group, and there was no significant difference between the mean ages of the groups. This is also noted in other previous studies in the literature.

Previous history of cholecystitis: Fibrosis due to previous inflammation may be considered as a challenging factor against dissection. Indeed, previous history of cholecystitis was more common in the PS group than the ONS group in our study. On the other hand, it is not listed in patient selection criteria in previous adult and pediatric studies. Holcomb et al. (16) mentioned a large percentage (22\%) of children who required hospitalization due to the complications of cholelithiasis, but the term "complication of cholelithiasis" may also have referred to obstructive incidents as well as cholecystitis.

Underlying hematological diseases: Concomitant pathologies such as hemoglobinopathies may prompt prolonged IHST following LC due to postoperative close follow-up or possible blood transfusions in both adults and children $(17,18)$. In our series, all the patients with hematological problems were assessed and prepared by a pediatric hematologist prior to anesthesia. In our study group, all sickle cell disease patients were monitored for at least one night. There was a significant difference between the ONS and PS groups in terms of concomitant underlying hematological diseases but we had solely one patient who required blood transfusion postoperatively due to the consumption coagulopathy as a major complication. Hence, the higher rate of patients with hematological diseases in the PS group probably relates to the surgeon's preference and the need for monitoring rather than a complication.

Perioperative complications-duration of anesthesia: Hepatobiliary surgery necessitates surgical skill and expertise because vascular or biliary abnormalities may be encountered. Esposito et al. (19) have mentioned 3\% of anatomic anomalies involving biliary duct and cystic artery. Due to the retrospective nature of our study, we refrained from commenting on anatomic variations as there may have been lacking information about anatomy in operative notes. Previous history of cholecystitis may also contribute to the 
duration of anesthesia due to fibrosis-related difficulty in dissection.

Oral feeding, postoperative nausea: Although overnight nasogastric drainage was previously favored, we find it unnecessary to keep drainage catheters postoperatively in cases without comorbidities $(10,19)$. In a study of short-term postoperative evaluation of complaints in adults, authors detected a severe postoperative nausea and vomiting (PONV) at a rate of $2 \%$ (20). Méndez et al. (9) discharged SDD patients after ingestion of clear liquids with no readmission and vomiting but Jawaheer et al. (11) reported a high PONV rate of $58 \%$ which dropped down to $0 \%$ after they changed the type of anesthesia (gaseous to intravenous), and the type of postoperative feeding regime from unrestricted to a light diet for 72 hours. In our practice, we don't use a strict feeding regime. Instead, feeding is started with water and clear liquids for a couple of hours, and if well-tolerated, we let patients switch to a moderately unrestricted diet. As mentioned before, there was no readmission for PONV in any of the groups under that approach.

Pain and anxiety: Pain management should certainly have an effect to some degree on IHST. Preoperative sedation with midazolam hydrochloride and the routine analgesic regimen (intraoperative diclofenac and acetaminophen with metamizole in the early postoperative period) used in our institution was equivalent and sufficient for all the patients in each group where we did not detect any significant difference between postoperative pain scores. The use of perioperative intravenous narcotics was favored in two recent pediatric series for better compliance but opioids were reported to have serious adverse effects $(11,12,20,21)$. Agarwal and Bagdi (10) used a bilateral subcostal transversus abdominis plane block under ultrasound guidance with similar pain scores to those of our study group.

In this study, the most significant factors to play a role on IHST were found to be the length of anesthesia and PTOF. Hence, this study is the only one to indicate the importance of "minimal invasiveness" and early oral feeding for shorter IHST in the pediatric population. As in an adult series, an ONS was recommended in the presence of intra-operative difficulties which may also seem to be rational for pediatric patients while the surgeon's choice may be different. Patients with underlying hematological diseases, previous history of cholecystitis, and prolonged duration of anesthesia due to perioperative complications are likely to be monitored longer before discharge.

\section{Study Limitations}

Due to the retrospective nature of this study, there may be some limitations. Records of pain scores and feeding times on nurse charts were filled out by a heterogenic group of nurses. Also clerical errors may have affected the discharge hours.

\section{Conclusion}

LC as day surgery may safely be performed in the pediatric population. Shorter duration of anesthesia and well-tolerated early oral feeding are the key factors for decision-making for these patients without co-morbidities. LC in the out-patient setting is thought to gain popularity as the number of experienced centers increase. Prospective and multicenter studies are necessary to define its precise psychological (both parents and children) and economical advantages.

\section{Ethics}

Ethics Committee Approval: The study was approved by the Ege University Local Ethics Committee (approval number: 17-5.2/6)

Informed Consent: Consent form was filled out by the parents of all participants.

Peer-review: Externally peer-reviewed.

\section{Authorship Contributions}

Surgical and Medical Practices: Z.D., E.D., G.Ö., A.Ç., O.E., Concept: Z.D., Design: Z.D., Data Collection or Processing: E.D., S.T., Analysis or Interpretation: Z.D., G.Ö., A.Ç., O.E., Literature Search: Z.D., Writing: Z.D.

Conflict of Interest: No conflict of interest was declared by the authors.

Financial Disclosure: The authors declared that this study received no financial support.

\section{References}

1. Carachi R, Young DG, Buyukunal C. A history of surgical paediatrics. Singapore, World Scientific Publishing Co Ltd, 2009.

2. Llorente J. Laparoscopic cholecystectomy in the ambulatory surgery setting. J Laparoendosc Surg 1992;2:23-6.

3. Stinson JN, Kavanagh T, Yamada J, Gill N, Stevens B. Systematic review of the psychometric properties, interpretability and feasibility of self-report pain intensity measures for use in clinical trials in children and adolescents. Pain 2006;125:143-7.

4. Smith M 2nd, Wheeler W, Ulmer MB. Comparison of outpatient laparoscopic cholecystectomy in a private nonteaching hospital versus a private teaching community hospital. JSLS 1997;1:51-3.

5. Campanelli G, Cavagnoli R, Cioffi U, De Simone M, Fabbiani M, Pietri P. Can laparoscopic cholecystectomy be a day surgery procedure? Hepatogastroenterology 1998;45:1422-9.

6. Lillemoe KD, Lin JW, Talamini MA, Yeo CJ, Snyder DS, Parker SD. Laparoscopic cholecystectomy as a "true" outpatient procedure: initial experience in 130 consecutive patients. J Gastrointest Surg 1999;3:44-9.

7. Vaughan J, Gurusamy KS, Davidson BR. Day-surgery versus overnight stay surgery for laparoscopic cholecystectomy. Cochrane Database Syst Rev 2013;31:CD006798.

8. Gurusamy K, Junarkar S, Farouk M, Davidson BR. Metaanalysis of randomized controlled trials on the safety and 
effectiveness of day-case laparoscopic cholecystectomy. $\mathrm{Br}$ J Surg 2008;95:161-8.

9. Méndez K, Sabater R, Chinea E, Lugo-Vicente H. Is there a safe advantage in performing outpatient laparoscopic cholecystectomy in children? J Pediatr Surg 2007;42:13336.

10. Agarwal P, Bagdi RK. Day case laparoscopic cholecystectomy in children: a review of 11 cases. J Indian Assoc Pediatr Surg 2014;19:61-4.

11. Jawaheer G, Evans K, Marcus R. Day-case laparoscopic cholecystectomy in childhood: outcomes from a clinical care pathway. Eur J Pediatr Surg 2013;23:57-62.

12. Dalton BG, Gonzales KW, Knott EM, St Peter SD, Aguayo P. Same day discharge after laparoscopic cholecystectomy in children. J Surg Res 2015;195:418-21.

13. Sacco Casamassima MG, Gause C, Yang J, Goldstein SD, Swarup A, Abdullah F. Safety of outpatient laparoscopic cholecystectomy in children: analysis of 2050 elective ACS NSQIP-pediatric cases. Pediatr Surg Int 2016;32:541-51.

14. Banieghbal B, Beale P. Day-case laparoscopic Nissen fundoplication in children. J Laparoendosc Adv Surg Tech A 2007;17:350-2.

15. Aguayo P, Alemayehu H, Desai AA, Fraser JD, St Peter SD. Initial experience with same day discharge after laparoscopic appendectomy for nonperforated appendicitis. J Surg Res 2014;190:93-7.

16. Holcomb GW, Morgan WM, Neblet WW, Pietsch JB, O'Neill JA Jr, Shyr Y. Laparoscopic cholecystectomy in children: Lessons learned from the first 100 patients. J Ped Surg 1999;34:1236-40.

17. Al-Mulhim AS, Alshehri MH. Laparoscopic cholecystectomy in adult patients with sickle cell disease. Surg Laparosc Endosc Percutan Tech 2012;22:454-8.

18. Al-Salem AH, Issa $H$. Laparoscopic cholecystectomy in children with sickle cell anemia and the role of ERCP. Surg Laparosc Endosc Percutan Tech 2012;22:139-42.

19. Esposito C, Alicchio F, Giurin I, Perricone F, Ascione G, Settimi A. Lessons learned from the first 109 laparoscopic cholecystectomies performed in a single pediatric surgery center. World J Surg 2009;33:1842-5.

20. Jensen $K$, Kehlet $H$, Lund CM. Post-operative recovery profile after laparoscopic cholecystectomy: a prospective, observational study of a multimodal anaesthetic regime. Acta Anaesthesiol Scand 2007;51:464-71.

21. Gurusamy K, Vaughan J, Toon CD, Davidson BR. Pharmacological interventions for prevention or treatment of postoperative pain in people undergoing laparoscopic cholecystectomy. Cochrane Database Syst Rev 2014;28:CD008261. 